\title{
EVALUASI PEMBELAJARAN SOSIOLOGI JENJANG SEKOLAH MENENGAH ATAS DI MASA PANDEMI COVID-19
}

\author{
Joan Hesti Gita Purwasih \\ Pendidikan Sosiologi, Universitas Negeri Malang \\ Jalan Semarang Nomor 5 Lowokwaru, Malang, Jawa Timur \\ e-mail: joan.hesti.fis@um.ac.id
}

\begin{tabular}{|c|c|c|c|c|c|}
\hline $\begin{array}{l}\text { Submitted } \\
2021-09-10\end{array}$ & $\begin{array}{c}\text { Accepted } \\
2021-10-23\end{array}$ & $\begin{array}{c}\text { Published } \\
\text { 2021-12-01 }\end{array}$ & open $\overbrace{\text { Access }}$ & (c) (i) (8) & asinta 3 \\
\hline
\end{tabular}

Abstrak
Penelitian bertujuan untuk menjelaskan fenomena hasil penilaian belajar Sosiologi jenjang sekolah menengah atas (SMA) di masa pandemi COVID-19. Evaluasi hasil belajar penting dilakukan karena di masa pandemi COVID-19, peserta didik di Jawa Timur justru dihadapkan dengan berbagai tes dalam menentukan kelulusan. Kebijakan tersebut sebenarnya bertentangan dengan keleluasaan yang disarankan oleh pemerintah, yaitu dengan menerapkan model nontes, seperi portofolio ataupun proyek. Jenis penelitian yang dilakukan adalah kualitatif deskriptif. Informan penelitian adalah guru-guru Sosiologi jenjang SMA yang tergabung dalam Musyawarah Guru Mata Pelajaran (MGMP) Sosiologi Kota Malang yang dipilih melalui teknik purposive sampling. Teknik pengumpulan data menggunakan wawancara dan data penelitian dianalisis menggunakan teknik analisis alir. Hasil penelitian menunjukkan bahwa guru dan peserta didik mengalami tekanan dan hasil tes yang diperoleh oleh peserta didik tidak memuaskan. Fenomena tersebut menjadi ironi dalam dunia pendidikan karena sebenarnya guru dan sekolah tahu bahwa pembelajaran di masa pandemi COVID-19 tidak mungkin optimal seperti pembelajaran tatap muka.

Kata Kunci: COVID-19; evaluasi pembelajaran; penilaian; tes.

\begin{abstract}
The research aimed to explain the phenomenon of sociological learning assessment results of high school students during a COVID-19 pandemic. Evaluation of learning is important to do because in the midst of the existing situation, students in East Java are actually faced with various tests in determining graduation. This policy actually contradicts the flexibility that has been suggested by the government, namely by applying the non-test model. The type of research used descriptive qualitative. Research informants were high school Sociology teachers who are members of the Malang City Sociology MGMP who were selected through purposive sampling technique. Meanwhile, the research data were analyzed using flow analysis techniques. The results showed that teachers and students experience pressure and the test results are certainly not satisfactory. This phenomenon is an irony in the world of education because actually teachers and schools know that learning during a COVID-19 pandemic may not be optimal like face-to-face learning.
\end{abstract}

Keywords: COVID-19; learning evaluation; assessment; test. 


\section{PENDAHULUAN}

Peserta didik diarahkan memiliki kecakapan 4C (communication, collaboration, creative, dan critical thinking). Kecakapan 4C sesungguhnya sejalan dengan amanat sistem pendidikan di Indonesia. Indonesia memiliki visi untuk mencetak setiap warga negara yang mampu mengembangkan potensi diri agar menjadi manusia yang beriman, bertakwa, berakhlak mulia, sehat, berilmu, cakap, kreatif, mandiri, dan demokratis, serta bertanggung jawab (SISDIKNAS, 2003). Amanat tersebut belum sepenuhnya dicapai dengan baik oleh Indonesia. Adapun pada taraf internasional, hasil Programme for International Student Assessment (PISA) menunjukkan bahwa di Indonesia cukup fluktuatif dan memiliki tren menurun (OECD 2019a; 2019b; 2019c), seperti data pada Tabel 1.

\section{Tabel 1 Hasil PISA Indonesia}

\begin{tabular}{cccc}
\hline \multirow{2}{*}{ Kompetensi } & \multicolumn{3}{c}{ Rata-Rata Skor PISA (Tahun) } \\
\cline { 2 - 4 } & $\mathbf{2 0 1 2}$ & $\mathbf{2 0 1 5}$ & $\mathbf{2 0 1 8}$ \\
\hline Membaca & 382,3 & 386 & 356 \\
Matematika & 375 & 386 & 379 \\
Sains & 382 & 403 & 396 \\
\hline
\end{tabular}

Hasil evaluasi internal melalui Ujian Nasional (UN) menunjukkan capaian penguasaan pengetahuan peserta didik juga masih rendah. Kondisi tersebut dapat diamati pada rata-rata nilai UN dari laporan Pusat Penilaian Pendidikan. Data pada Gambar 1 dan Gambar 2 menunjukkan hasil Ujian Nasional Berbasis Komputer (UNBK) dan Ujian Nasional Berbasis Kertas dan Pensil (UNKP) tiga tahun terakhir, baik untuk sekolah negeri dan swasta di jenjang SMP/MTs serta SMA/MA (Pusat Penilaian Pendidikan, 2019).

Berdasarkan data pada Gambar 1 dan Gambar 2, diketahui bahwa hasil UN memiliki kecenderungan fluktuatif dari tahun ke tahun dengan capaian nilai ratarata yang rendah. Hasil UN untuk SMP dan SMA cenderung lebih tinggi dibandingkan MTs dan MA. Situasi tersebut berarti bahwa kualitas pendidikan Indonesia secara umum tampak belum mencapai hasil yang maksimal. Oleh karenanya, kurikulum di Indonesia harus terus mengalami perubahan dalam bingkai penyempurnaan. 


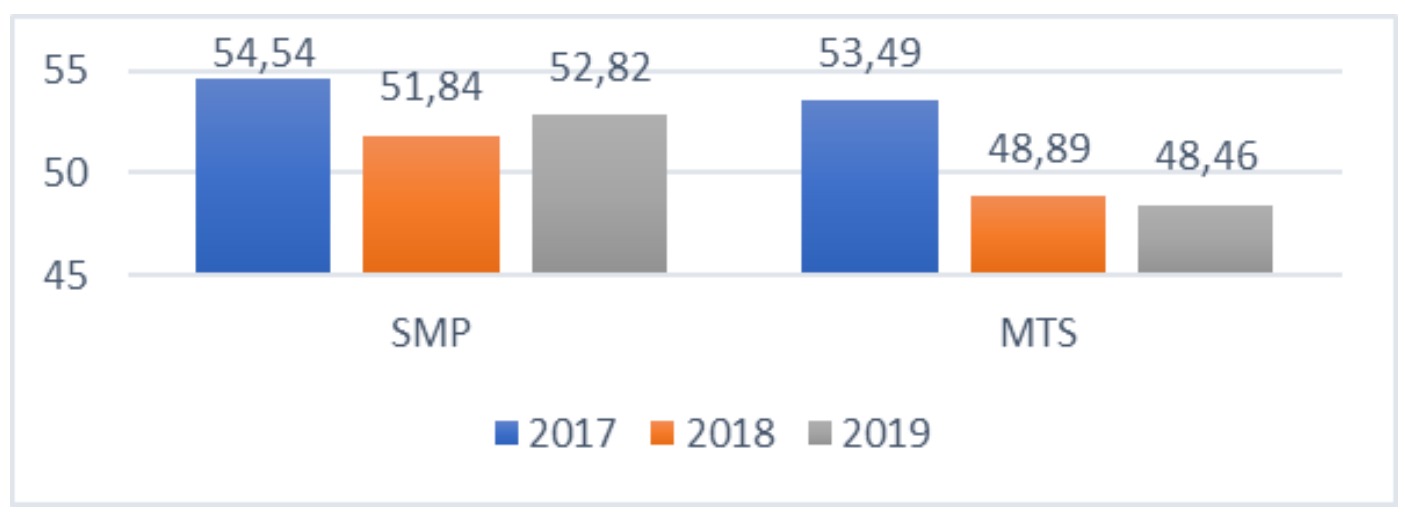

\section{Gambar 1 Hasil UN SMP-MTs}

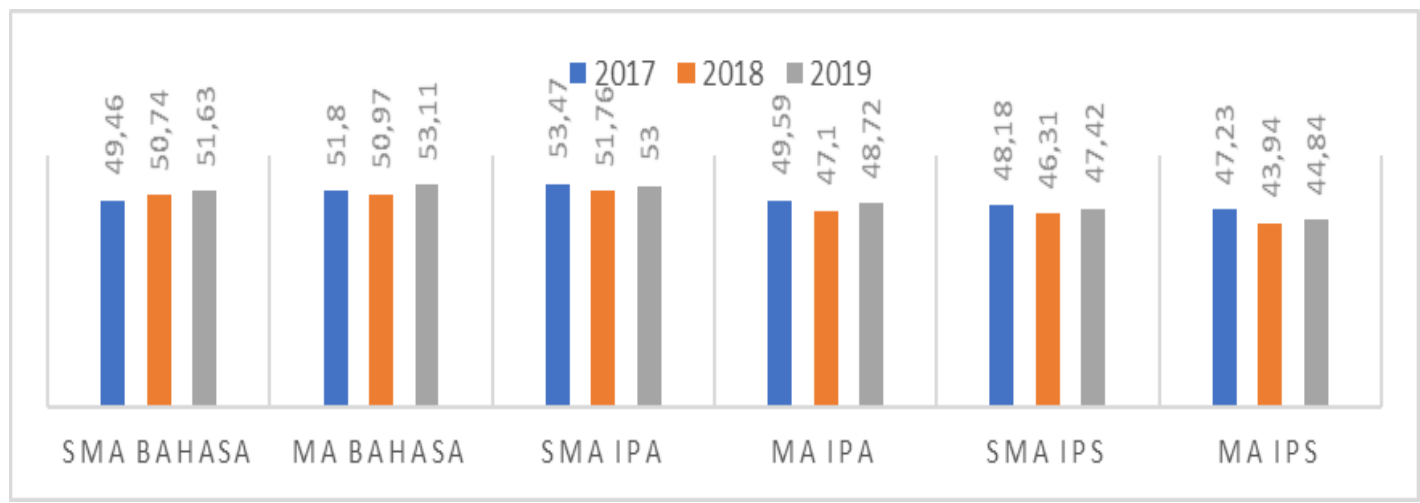

\section{Gambar 2 Hasil UN SMP-MTs dalam 3 Tahun Terakhir}

Kementerian Pendidikan dan Kebudayaan juga terus berbenah, salah satunya dengan membuat kebijakan-kebijakan. Tahun 2019 pemerintah membuat empat pilar kebijakan yang disebut dengan "Merdeka Belajar" yang meskipun UN dihapuskan dan terakhir dilaksanakan pada tahun 2020, bukan berarti sistem evaluasi capaian pembelajaran berhenti. Bencana COVID-19 memang menyebabkan UN di tahun 2020 terhenti. Ujian sekolah untuk kelulusan dapat menggunakan tes jika pelaksanaannya telah dilakukan sebelum surat edaran pemerintah turun atau mampu melakukannya melalui jarak jauh. Sekolah dapat melakukan metode lain, yaitu portofolio atau bentuk penilaian lainnya yang tidak memberatkan dan aman bagi peserta didik (Kemdikbud, 2020).

Kondisi serupa juga berlanjut pada tahun 2021, UN ditiadakan dan nilai rapor menjadi dasar untuk menentukan kelulusan. UN ditiadakan untuk seterusnya dan diubah menjadi bentuk Asesmen Nasional (AN) yang terdiri atas Asesmen 
Kompetensi Minimum (AKM), survei karakter, dan survei lingkungan belajar. Penelitian terdahulu menunjukkan bahwa AN ternyata tidak sepenuhnya dipahami oleh guru ataupun peserta didik, banyak pihak berupaya melakukan berbagai persiapan untuk bisa mencapai AN dengan optimal (Muta'ali, 2020). Fenomena tersebut menunjukkan bahwa masyarakat belum memahami pandangan baru evaluasi nasional Indonesia.

Evaluasi kini melihat proses yang berjalan, tidak hanya fokus pada hasil akhir seperti UN karena AN tidak dilakukan di akhir jenjang. Upaya tersebut juga menandakan bahwa evaluasi yang ada bersifat lentur dan mengakomodasi berbagai aspek. Evaluasi kini juga bersifat menyeluruh karena pemerintah menyoroti masalah pendidikan secara holistik dan kompleks tidak hanya dari hasil belajar. Pemerintah menyoroti masalah dengan menyurvei kondisi guru, sekolah, dan lingkungan peserta didik. Evaluasi yang dilakukan melalui AN selanjutnya dimanfaatkan untuk perbaikan. Hasil yang diperoleh nantinya dilaporkan, diberi masukan, dan diimbangi berbagai program pendampingan yang membangun.

Arah kebijakan baru tersebut tidak sepenuhnya dipahami dan diimplementasikan dengan baik di beberapa daerah, salah satunya di Jawa Timur (Rahma, 2021). Selama pandemi COVID-19, kenyataannya sebagian peserta didik di Jawa Timur masih mengalami ujian/tes bertubi-tubi. Misalnya, peserta didik ternyata masih melakukan tes berupa Ujian Sekolah (istilah untuk ujian akhir semester), Ujian Satuan Pendidikan (ujian sekolah yang terdiri atas praktik dan tulis), serta Evaluasi Hasil Belajar Berbasis Komputer dan Smartphone (EHBBKS) 2020/2021 (Dinas Pendidikan Provinsi Jawa Timur, 2021). Melihat realitas tersebut, peneliti melakukan evaluasi terhadap hasil belajar mata pelajaran Sosiologi yang terkait rentetan ujian/tes tersebut.

Mata pelajaran Sosiologi di jenjang SMA dipilih sebagai sasaran utama karena adanya berbagai pertimbangan. Pertama, UN tahun 2019 menunjukkan daya serap soal pada materi Esensial Sosiologi masih rendah. Peneliti ingin mengetahui ada tidaknya peningkatan atas capaian sebelumnya di masa pandemi COVID-19. Fokus hasil evaluasi yang dipotret adalah tahun ajaran 2020/2021. Kedua, mata pelajaran Sosiologi memiliki kekhasan ilmu yang seharusnya 
mendorong peserta didik melakukan pengamatan lapangan/lingkungan sosial. Akan tetapi, kondisi di masa pandemi COVID-19 membatasi keleluasaan belajar peserta didik. Akibatnya, hal tersebut menjadi tantangan tersendiri bagi guru dalam membelajarkan Sosiologi. Peneliti menggali alasan sekolah tetap melakukan tes sebagai alat ukur utama selama pandemi COVID-19, dampaknya bagi peserta didik, hasil tes tersebut, dan juga tantangan yang perlu disikapi dalam menghadapi perubahan yang terjadi.

\section{METODE}

Peneliti menggunakan metode kualitatif deskriptif untuk menggambarkan penggunaan tes selama pandemi COVID-19, yaitu Ujian Satuan Pendidikan (USP) serta Evaluasi Hasil Belajar Berbasis Komputer dan Smartphone (EHBBKS). Penelitian dilakukan di Kota Malang, Jawa Timur. Peneliti melakukan wawancara terstruktur kepada lima guru Sosiologi di Kota Malang yang tergabung dalam Musyawarah Guru Mata Pelajaran (MGMP) Sosiologi Kota Malang dengan latar belakang sekolah berbeda. Penentuan informan dilakukan dengan teknik purposive sampling. Informasi identitas guru dan sekolah tidak dapat peneliti tunjukkan karena menjaga kode etik dan melindungi privasi dari para informan.

Kriteria pemilihan informan, yaitu merupakan guru Sosiologi dari SMA negeri dan swasta di Kota Malang, menerapkan USP berbasis tes, dan EHB-BKS dengan memberikan beberapa pertanyaan yang meliputi: (1) Apakah Bapak/Ibu bekerja sebagai guru Sosiologi di SMA negeri/swasta di Kota Malang? (2) Apakah Bapak/Ibu menggunakan tes dalam ulangan harian selama tahun ajaran 2020/2021? (3) Apakah Bapak/Ibu menggunakan tes dalam USP tahun ajaran 2020/2021? dan (4) Apakah sekolah Bapak/Ibu mengikuti EHB-BKS tahun ajaran $2020 / 2021$ ?

Tahap selanjutnya peneliti melakukan validitas data melalui triangulasi sumber dan pengolahan data melalui teknik analisis alir. Teknik analisis alir dilakukan dengan reduksi data, display data, dan penarikan kesimpulan (Creswell, 2014). Implementasi langkah-langkah tersebut yaitu hasil wawancara peneliti 
diolah dengan membuat pengelompokan (matrik) yang terdiri atas kategorisasi tahapan persiapan dan pascapelaksanaan ujian. Kategori persiapan ujian fokus pada alasan pelaksanaan tes dan upaya yang dilakukan guru ataupun sekolah. Kategori pelaksanaan tes fokus pada hasil dan dampaknya bagi peseta didik. Kisikisi wawancara dapat dilihat pada Tabel 2.

Tabel 2 Kisi-Kisi Wawancara

\begin{tabular}{ll}
\hline \multicolumn{1}{c}{ Tujuan yang Disasar } & \multicolumn{1}{c}{ Indikator } \\
\hline Implementasi penilaian hasil belajar di & Jenis penilaian yang diterapkan di \\
sekolah Bapak/Ibu pada masa pandemi & sekolah; \\
COVID-19. & Jenis instrumen penilaian yang \\
& sering digunakan; \\
& Bentuk penilaian yang digunakan \\
& untuk kenaikan kelas dan kelulusan. \\
& Persiapan sekolah menghadapi \\
Bagaimana implementasi EHB-BKS di & EHB-BKS; \\
sekolah Bapak/Ibu? & Pelaksanaan EHB-BKS; \\
& Hasil EHB-BKS dan \\
& pemanfaatannya; \\
& Hasil penilaian Sosiologi selama \\
Bagaimana hasil belajar Sosiologi di masa & pandemi COVID-19; \\
pandemi COVID-19? & Materi yang memiliki daya serap \\
& rendah; \\
& Penyebab/kendala daya serap materi \\
& yang rendah; \\
& Upaya yang dilakukan untuk \\
& menyikapi hasil belajar. \\
\hline
\end{tabular}

\section{HASIL DAN PEMBAHASAN}

\section{Alasan Sekolah Tetap Menyelenggarakan Tes di Masa Pandemi COVID-19}

Pandemi COVID-19 menyebabkan pembatasan aktivitas pembelajaran di sekolah. Kondisi tersebut sebenarnya beragam dan bergantung pada perkembangan COVID-19 di masing-masing daerah. Kebijakan tatap muka memang diperkenankan, namun dengan tetap mematuhi protokol kesehatan yang ketat. Sebagian sekolah di Kota Malang kenyataannya tetap melaksanakan tes di sekolah secara tatap muka. Banyak sekolah di Kota Malang tidak memanfaatkan 
alternatif penilaian nontes seperti portofolio sebagai penentu kelulusan. Hal tersebut menjadi tanda tanya besar karena sebenarnya cukup berisiko dan memberikan dampak psikologis bagi peserta didik selama pandemi COVID-19. Penelitian terdahulu telah membuktikan bahwa tes sebagai penentu kelulusan banyak membawa dampak negatif seperti UN sebelumnya dan UN menyebabkan kecemasan tidak hanya pesera didik, tetapi juga guru dan orang tua (Arjanto, 2016; Solehah, 2012). Pembelajaran yang diselenggarakan sekolah banyak berorientasi UN dan kecurangan terindikasi meningkat (Berkhout et al., 2020).

Tes kenyataannya tetap menjadi primadona di masa pandemi COVID-19 dalam menilai hasil capaian belajar peserta didik (Andiarna \& Kusumawati, 2020). Berdasarkan hasil penelitian tersebut, bentuk tes yang paling banyak adalah pilihan ganda. Para informan mengemukakan bahwa pilihan ganda memiliki keunggulan yang sulit untuk ditinggalkan, yaitu cepat, akurat, dan mudah diolah. Peserta didik hanya tinggal memilih salah satu jawaban benar, lalu sistem akan mendeteksi dan memberikan jumlah skor hingga nilai yang diperoleh. Adapun pada EHB-BKS SMA, komposisi soal yang dikeluarkan dalam ujian tersebut terdiri atas pilihan ganda (30\%), pilihan ganda kompleks (45\%), menjodohkan (10\%), isian singkat (5\%), dan uraian (10\%) (Dinas Pendidikan Provinsi Jawa Timur, 2021). Informan mengatakan bahwa level satuan pendidikan/sekolah yang menggunakan model penilaian tes pada kenyataannya banyak diterapkan dibandingkan nilai lain seperti portofolio. Seluruh informan (guru) yang peneliti wawancarai menyatakan model penilaian tes masih digunakan dan mendapat izin dari sekolah, padahal rekomendasi bentuk ujian nontes telah disarankan dan diperbolehkan oleh pemerintah.

Faktor kebijakan dari pusat ke daerah pada kenyataannya menjadikan setiap sekolah wajib melakukan tes, misalnya pada fenomena EHB-BKS. Alasan diadakannya tes tersebut disinyalir adalah untuk mengevaluasi dan memetakan kualitas pendidikan di Jawa Timur. Sikap pemerintah tersebut tentu membawa dampak positif maupun negatif serta dinilai pro dan kontra oleh masyarakat. Keberhasilan pemerintah dalam memutakhirkan teknologi tes berbasis jarak jauh 
perlu diapresiasi. Risiko penularan COVID-19 juga harus diwaspadai, meskipun teknis pelaksanaannya sudah diatur untuk meminimalkan dampak tersebut.

\section{Dampak Penyelenggaraan Tes bagi Peserta Didik}

Penyelenggaraan evaluasi belajar melalui jalur tes menyebabkan dampak signifikan bagi peserta didik, yaitu stres dan nilai tidak memuaskan. Informan menyatakan bahwa pandemi COVID-19 menyebabkan peserta didik tidak dapat belajar optimal karena adanya keterbatasan teknologi, aksesibilitas, bahkan waktu atau durasi belajar. Kebijakan pemerintah yang tertuang dalam Kepmendikbud Nomor 719/P/2020 tentang Pedoman Pelaksanaan Kurikulum pada Satuan Pendidikan dalam Kondisi Khusus Tahun 2020 menyatakan bahwa sekolah dapat ditolerir jika tidak mampu menyelesaikan seluruh Kompetensi Dasar (KD) yang seharusnya. Kenyataannya, di lapangan menunjukkan sebagian besar sekolah tetap mengajarkan semua KD meski dalam situasi pandemi COVID-19.

Selain materi yang tidak berkurang, guru, dan peserta didik juga diarahkan sekolah untuk beradaptasi dengan soal-soal bernuansa Asesmen Kompetensi Minimum (AKM). AKM hanyalah salah satu bagian dari survei nasional yang tidak menentukan lulusan dan hanya diikuti oleh sebagian peserta didik (sampling). Kebijakan tersebut nampaknya masih diinterpretasikan sekolah sebagai pengganti UN. Sekolah mewajibkan guru, padahal soal-soal AKM hanya mengasah keterampilan literasi dan juga numerasi peserta didik. Menurut informan, guru-guru di sekolah menginterpretasikan soal AKM hanya berdasarkan pada bentuk soal yang khas seperti pilihan ganda kompleks, menjodohkan, benar-salah, dan isian. Pengintegrasian literasi dan numerasi dalam soal mata pelajaran yang bersifat kontekstual justru sering terabaikan. Penerimaan AKM yang salah membuat tekanan bagi guru dan peserta didik. Peserta didik dipaksa mengerjakan soal-soal bernuansa AKM tersebut di tengah pandemi COVID-19 dengan dalih agar peserta didik familier dengan EHB-BKS.

Penguatan literasi dan numerasi seharusnya dilakukan secara bertahap dan berkelanjutan, tentunya melalui praktik baik pembelajaran di sekolah (Firda, 2021; Nurcahyo, 2020). Tujuan membiasakan soal-soal AKM di sekolah 
seharusnya didahului dengan praktik baik pembiasaan literasi dan numerasi dalam proses pembelajaran ataupun di lingkungan sekolah. Keterampilan tersebut harus diasah dan didukung dengan fasilitas dan sumber daya manusia yang memadai sehingga memperoleh hasil optimal karena budaya literasi masyarakat Indonesia masih rendah (Dinata, 2021; Rahmania, 2021; Fatmawati \& Safitri, 2020).

Kegagalan peserta didik dalam EHB-BKS nampaknya menjadi momok yang ditakutkan sekolah. Seluruh informan mengaku awalnya hasil EHB-BKS akan dijadikan sebagai salah satu pertimbangan kelulusan. Akan tetapi, kenyataannya baik hasil EHB-BKS ataupun USP peserta didik di seluruh sekolah informan tidaklah memuaskan. Seluruh informan mengaku "mengatrol" nilai yang ada dengan berbagai cara. Hasil EHB-BKS yang akhirnya berujung pada dokumen rahasia sekolah yang hasilnya tidak dirilis baik oleh pemerintah ataupun satuan pendidikan. Fenomena yang ironis seharusnya tidak terjadi jika pemerintah, guru, dan sekolah memahami bahwa pandemi COVID-19 adalah pukulan besar bagi proses pembelajaran di Indonesia. Materi yang disampaikan selama pandemi COVID-19 tentu tidak dapat diserap dengan baik karena keterbatasan yang ada.

\section{Hasil Belajar dan Tantangan Pembelajaran Sosiologi}

Terkait hasil belajar Sosiologi, kenyataannya seluruh informan di sekolahsekolah di Kota Malang menyatakan hasil USP dan EHB-BKS yang telah diselenggarakan tidaklah memuaskan. Informan menyatakan materi-materi Sosiologi yang bersifat teknis dan membutuhkan praktik, seperti penelitian sosial, pemberdayaan, dan evaluasi pemberdayaan sulit untuk diterapkan selama pandemi COVID-19. Akibatnya, pemahaman peserta didik atas materi-materi tersebut juga rendah dalam hasil USP dan EHB-BKS. Hal tersebut ditunjukkan dengan refleksi guru atas hasil ujian peserta didik.

Kondisi yang demikian mencerminkan adanya tantangan tersendiri dalam menyampaikan materi-materi Sosiologi di masa pandemi COVID-19. Hasil belajar seharusnya disikapi dengan evaluasi pembelajaran yang holistik sehingga perbaikan dapat dilakukan guru dan sekolah. Upaya tersebut penting dilakukan 
karena kondisi pandemi COVID-19 tidak dapat diprediksi dengan pasti. Perpanjangan pembatasan sosial dan pembelajaran jarak jauh masih menjadi tanda tanya. Artinya, sekolah, guru, dan peserta didik harus siap menghadapi situasi tersebut dalam kurun waktu yang tidak menentu (unpredictable condition).

Permasalahan pendidikan yang terjadi dalam perspektif morphogenesis dapat dianalisis menggunakan tiga aspek, yaitu struktur, kultur, dan agen yang berubah dari waktu ke waktu (Archer \& Archer, 1995). Ketika pandemi COVID19 terjadi, agen yang berperan penting dalam menentukan arah kebijakan pendidikan di lapangan adalah sekolah. Artinya, kepala sekolah menjadi penentu kunci (agen) yang seharusnya memiliki pandangan kritis dalam menjembatani kebijakan di tingkat pusat dan daerah. Satuan pendidikan/sekolah sebenarnya memiliki kebebasan mutlak untuk menentukan bentuk evaluasi pembelajaran di masa pandemi COVID-19. Kenyataannya agen tidak mampu menunjukkan penolakan atas struktur yang diberlakukan daerah (EHB-BKS). Akhirnya agen justru mengikuti struktur yang bersifat kebijakan top-down, sementara kultur yang ada tidak siap menghadapi kondisi tersebut. Akhirnya, culture shock yang dirasakan guru dan peserta didik mengakibatkan tekanan yang bertubi-tubi dirasakan selama pandemi COVID-19.

Realitas tersebut harus menjadi pelajaran berharga bagi sekolah untuk memperbaiki kualitas model evaluasi pembelajarannya di masa pandemi COVID19. Fenomena juga bisa menjadi pelajaran berharga untuk bisa menyiapkan calon pendidik masa depan. Program studi dalam bidang pendidikan harus meningkatkan calon lulusannya, misalkan dengan pemutakhiran kurikulum atau melakukan kolaborasi dengan sekolah, baik dalam pengabdian dan penelitian (Purwasih et al., 2021). Hal tersebut penting karena calon pendidik pada umumnya sulit mengembangkan kompetensinya karena kurang pemahaman yang mendalam dalam membuat soal, memahami materi terkini di sekolah, dan waktu belajar di perkuliahan kurang memadai (Purwasih, 2020), serta mendukung program-program MBKM yang bisa diintegrasikan di sekolah. 


\section{SIMPULAN}

Berdasarkan hasil penelitian, maka disimpulkan bahwa peserta didik memperoleh banyak tes di masa pandemi COVID-19. Hal tersebut mengakibatkan guru dan peserta didik mengalami tekanan dan hasil tes tidak memuaskan. Fenomena yang demikian menjadi ironi dalam dunia pendidikan karena sebenarnya guru dan sekolah tahu bahwa pembelajaran di masa pandemi COVID19 tidak mungkin optimal seperti pembelajaran tatap muka. Struktur yang bersifat top-down selalu memiliki posisi superior yang mampu memudarkan kekuatan agen. Struktur yang mudah berubah terus-menerus memberikan tekanan dalam pembelajaran (kultur).

\section{UCAPAN TERIMA KASIH}

Terima kasih peneliti ucapkan kepada Fakultas Ilmu Sosial Universitas Negeri Malang yang telah memberikan bantuan pendanaan untuk melakukan penelitian dengan Nomor Surat 5.8.22/UN32.7/KP/2021.

\section{DAFTAR PUSTAKA}

Andiarna, F., \& Kusumawati, E. (2020). Pengaruh Pembelajaran Daring terhadap Stres Akademik Mahasiswa Selama Pandemi COVID-19. Jurnal Psikologi, 16(2), 139-149. http://dx.doi.org/10.24014/jp.v16i2.10395.

Archer, M. S., \& Archer, M. S. (1995). Realist Social Theory: The Morphogenetic Approach. Cambridge: Cambridge University Press.

Arjanto, P. (2016). Identifikasi Tingkat Stres Peserta Didik Menjelang Ujian Nasional pada Jenjang Pendidikan Menengah. JKI (Jurnal Konseling Indonesia), 1(2), 96-100. https://doi.org/10.21067/jki.v1i2.1621.

Berkhout, E., Pradhan, M., \& Suryadarma, D. (2020). From Cheating to Learning: An Evaluation of Fraud Prevention on National Exams in Indonesia dalam https://rise.smeru.or.id/en/publication/cheating-learningevaluation-fraud-prevention-national-exams-indonesia. Diakses September 2021.

Creswell, J. W. (2014). Penelitian Kualitatif dan Desain Riset, Memilih di Antara 
Lima Pendekatan (S. Z. Qudsy (ed.); 3rd ed.). Yogyakarta: Pustaka Pelajar. Dinas Pendidikan Provinsi Jawa Timur. (2021). Pedoman Teknis (Domnis) Penyelenggaraan Ujian Satuan Pendidikan (USP) dan Evaluasi Hasil Belajar Berbasis Komputer dan Smartphone (EHB-BKS) SMA Negeri dan Swasta Tahun Pelajaran 2020/2021 dalam https://www.ibadjournals.com/2021/02/domnis-usp-dan-ehb-bks-2021.html. Diakses 1 September 2021.

Dinata, K. (2021). Analisis Kemampuan Literasi Digital Mahasiswa. Edukasi: Jurnal Pendidikan, 19(1), 105-119. http://dx.doi.org/10.31571/edukasi.v19i1.2499.

Fatmawati, E., \& Safitri, E. (2020). Kemampuan Literasi Informasi dan Teknologi Mahasiswa Calon Guru Menghadapi Pembelajaran di Era Revolusi Industri 4.0. Edukasi: Jurnal Pendidikan, 18(2), 214-224. http://dx.doi.org/10.31571/edukasi.v18i2.1863.

Firda, F. R. (2021). Pelaksanaan Gerakan Literasi Wujud Pendidikan Karakter Gemar Membaca pada Pelajaran PPKN SMA Santo Benediktus Pahauman Kabupaten Landak. Jurnal Pendidikan Kewarganegaraan, 5(1), 51-63. http://dx.doi.org/10.31571/pkn.v5i1.2258.

Kepmendikbud Nomor 719/P/2020 tentang Pedoman Pelaksanaan Kurikulum pada Satuan Pendidikan dalam Kondisi Khusus dalam https://www.kemdikbud.go.id/main/blog/2020/08/kemendikbud-terbitkankurikulum-darurat-pada-satuan-pendidikan-dalam-kondisi-khusus. Diakses 12 September 2021

Kemdikbud. (2020). Surat Edaran Mendikbud Nomor 4 Tahun 2020 tentang Pelaksanaan Kebijakan Pendidikan dalam Masa Darurat Penyebaran Corona Virus Disease (Covid-19)-Pusdiklat Pegawai Kementerian Pendidikan dan Kebudayaan dalam https://pusdiklat.kemdikbud.go.id/suratedaran-mendikbud-no-4-tahun-2020-tentang-pelaksanaan-kebijakanpendidikan-dalam-masa-darurat-penyebaran-corona-virus-disease-covid-1-

9. Diakses 1 September 2021.

Muta'ali, J. A. (2020). Opini Masyarakat tentang Asesmen Nasional sebagai 
Penganti Ujian Nasional. Journal of Chemical Information and Modeling, 53(9), 1689-1699.

Nurcahyo, M. A. (2020). Penggunaan Multimedia Interaktif untuk Meningkatkan Literasi Digital Siswa SMP pada Mata Pelajaran IPA. Jurnal Pendidikan $\begin{array}{llll}\text { Informatika dan } & \text { Sains, } & \text { 9(2), }\end{array}$ http://dx.doi.org/10.31571/saintek.v9i2.2077.

OECD. (2019a). Mathematics Performance (PISA) dalam https://www.oecdilibrary.org/education/reading-performancepisa/indicator/english_79913c69-en. Diakses 1 September 2021. https://doi.org/10.1787/79913c69-en.

OECD. (2019b). Reading Performance (PISA) (Indicator) dalam https://www.oecd-ilibrary.org/education/reading-performancepisa/indicator/english_79913c69-en. Diakses 1 September 2021. https://doi.org/10.1787/79913c69-en.

OECD. (2019c). Science Performance (PISA) dalam https://www.oecdilibrary.org/education/science-performance-

pisa/indicator/english_91952204-en. Diakses 1 September 2021. https://doi.org/10.1787/91952204-en.

Purwasih, J. H. G. (2020). Kendala Calon Pendidik dalam Membuat Soal Pilihan Ganda Higher Order Thinking (HOT). Jurnal Sosial Humaniora, 13(1), 1222. https://doi.org/10.12962/j24433527.v13i1.6746.

Purwasih, J. H. G., Kurniawati, E., Hadi, N., \& Utami, I. W. P. (2021). Developing an Independent Curriculum: Village Development Project as an Equalization of Thesis. International Journal of Emerging Technologies in Learning, 16(7), 135-145. http://dx.doi.org/10.3991/ijet.v16i07.21225.

Pusat Penilaian Pendidikan. (2019). Grafik Capaian Nasional dalam https://hasilun.puspendik.kemdikbud.go.id/\#2017-20182019!sma!capaian_nasional!99\&99\&999!a\&01\&T\&T\&1\&T!1!\&. Diakses 12 September 2021.

Rahma, S. (2021). UN Ditiadakan, Disdik Jatim Bikin Domnis Evaluasi Belajar Online dalam https://radarmalang.jawapos.com/malang-raya/17/02/2021/un- 
Edukasi: Jurnal Pendidikan, Volume 19 Nomor 2 Tahun 2021

Evaluasi Pembelajaran Sosiologi Jenjang Sekolah Menengah Atas.......

Joan Hesti Gita Purwasih

Halaman 216-229

ditiadakan-disdik-jatim-bikin-domnis-evaluasi-belajar-online. Diakses 12 September 2021.

Rahmania, L. A. (2021). Optimalisasi Gerakan Literasi Sekolah dalam Persiapan Asesmen Nasional. JoLLA: Journal of Language, Literature, and Arts, 1(4), 450-461. https://doi.org/10.17977/um064v1i42021p450-461.

SISDIKNAS. (2003). Undang-Undang Republik Indonesia Nomor 20 Tahun 2003 $\begin{array}{llll}\text { tentang } & \text { Sistem } & \text { Pendidikan }\end{array}$ https://peraturan.bpk.go.id/Home/Details/43920/uu-no-20-tahun-2003.

Diakses 1 September 2021.

Solehah, L. F. N. (2012). Faktor-Faktor Penyebab Kecemasan Siswa dalam Menghadapi Ujian Nasional. Perspektif Ilmu Pendidikan, 25(XVI), 16-32. https://doi.org/10.21009/PIP.251.3. 